\title{
Konya il merkezinde gastroözofageal reflü hastalığı prevalansı
}

\author{
Prevalence of gastroesophageal reflux in the central province of Konya
}

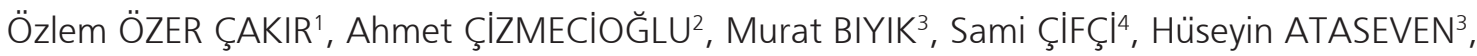 \\ Hakkı POLAT ${ }^{3}$, Ali DEMIR ${ }^{3}$ \\ ${ }^{1}$ Alanya Alaaddin Keykubat Üniversitesi, Tıp Fakültesi, Gastroenteroloji ve Hepatoloji Bilim Dalı, Antalya \\ ${ }^{2}$ Konya Farabi Hastanesi, İç Hastalıkları Kliniği, Konya \\ ${ }^{3}$ Necmettin Erbakan Üniversitesi, Meram Tıp Fakültesi, Gastroenteroloji ve Hepatoloji Bilim Dalı, Konya \\ ${ }^{4}$ SBÜ Kanuni Sultan Süleyman Eğitim ve Araştırma Hastanesi, Gastroenteroloji ve Hepatoloji Kliniği, İstanbul
}

\begin{abstract}
Giriş ve Amaç: Gastroözofageal reflü hastalığı üst gastrointestinal kanalın sık rastlanılan bir hastalığıdır. Anatomik lokalizasyonu nedeniyle özofagusa komşuluğu olan organların hastalıklarını taklit edebildiği gibi; asıl hastalığın şikayetini maskeleyebilmekte hatta oluşan komplikasyonları da başka organların fonksiyonlarını bozabilmektedir. Dünyada batı tipi yaşantısı olan toplumlarda daha sık görülmektedir. Türkiye'de hastalık epidemiyolojisi ile sınırı veri vardır. Gereç ve Yöntem: Yaşadığımız çevrenin prevalansını belirleyebilmek amaçı yapılan çalışmada Konya Ili Merkez Ilçelerinde önceden belirlenmiş rastgele adreslerdeki 2000 kişi ile anket görüşmesi yapılmıştır. Bulgular: 1188 kişi ile anket tamamlanabilmiş, (\%59 geri dönüş oranı), katılımcıların 581'i kadın (\%48.9), 607'si erkek (\%51.1), yaş ortalaması 41.34 12.8 olarak hesaplanmıştır. Aylık semptomlar göz önüne alındığında aylık \%10,9 prevalans bulunmuştur. Cinsiyet, medeni hal, eğitim düzeyi, meslek ve gelir durumu reflü ile ilişkili bulunmazken yaş ve vücut kitle indeksi ile korelasyon saptanmıştır $(p<0.05)$. Sonuç: Bulunan sonuç itibariyle Konya Ili merkez ilçelerinde her üç kişiden birinin kilolu ya da obez olduğu saptanmış, reflü prevalansının batı ülkelerine yakın olduğu görülmüştür.
\end{abstract}

Anahtar kelimeler: Gastroözofageal reflü, prevalans, Konya
Background and Aims: Gastroesophageal reflux is a common disease of the upper gastrointestinal tract. Because of the localization of esophagus, gastroesophageal reflux can mimic the disease symptoms of other organs and mask the symptoms of the main illness. Furthermore, some of its complications can impair the functions of other organs. Reflux is common in the Western-societies; however, in Turkey, there is limited data related to the epidemiology of this disease. Therefore, this study aimed to determine the prevalence of gastrointestinal reflux in Turkey. Materials and Methods: In this study, 2000 individuals were randomly interviewed in the predetermined addresses of the central districts of Konya. Results: The questionnaire was completed by 1188 subjects (response rate, 59\%), including 581 (48.9\%) women and 607 (51.1\%) men. The mean age of participants was $41.34 \pm 12.8$ years. Gastroesophageal symptoms were prevalent in $10.9 \%$ of the study population. There were no significant associations between gastroesophageal reflux disease and sex, marital status, level of education, profession, or level of income. However, age and body mass index had a significant positive correlation with gastroesophageal reflux disease $(p<0.05)$. Conclusion: This study demonstrated that one of every three subjects in the central region of Konya was overweight or obese and the prevalence of gastroesophageal reflux was similar to that in the Western countries.

Key words: Gastroesophageal reflux, prevalence, Konya

\section{GIRISS}

Gastroözofageal reflü hastalığı (GÖRH), mide veya duedenum içeriğinin özofagusa geçerek semptomlara ve histopatolojik hasara neden olması durumudur. Birçok önemli hastalığın benzer şikayetleri olması sebebiyle çoğu zaman diğer hastalıklar dışlandıktan sonra akla gelen; buna rağmen toplumda sık rastlanan bir sağlık sorunudur. Oysa masum gibi görülen hastalık; semptomları nedeniyle sadece kişinin yaşam kalitesini etkilemekle kalmamakta, komplikasyonları ile de orta derecede morbidite ve mortaliteye de neden olmaktadır $(1,2)$. Kaybettirdiği iş gücü kaybı ve maliyetler de değerlendirilecek olunursa

hastalığın boyutu daha iyi görülebilir. Amerikan Gastroenteroloji Birliği'ne (AGA-American Gastroenterological Association) göre GÖRH için, prevalansın \%6 civarında olduğu 2000 yılında bile yaklaşık olarak 24 milyar dolar kadar harcama yapılmıştır $(2,3)$. Antireflü mekanizmaların bozulması sonucu oluşan GÖRH, toplumun farklı kesimlerinde farklı yüzdelerde görülmekte olup haftalık şikayet \%4 ile \%20 arasında değişkenlik göstermektedir. Batı dünyasında sıklık daha da artmaktadır. GÖRH, Amerikan Gastroenteroloji Koleji (American College of Gastroenterology-ACG) tarafından mide içeriğinin özofagusa 
anormal biçimde geçişi ile oluşan semptomlar topluluğu ve mukozal hasar olarak tanımlanmıştır (2). Bir başka görüş, Montreal Sınıflandırması (The Montreal Classification-TMC), mide reflüsünün semptomlara ve komplikasyonlara yol açtığı durumda hastalık olarak kabul edilebileceğini tanımlamıştır (3).

Reflü hastalığının ana semptomları mide yanması (heartburn) ve regürjitasyondur.Bu sebeple epidemiyolojik tahminlerde hastalık prevalansı ana semptomların olup olmamasına göre yapılmaktadır (4). Ancak hastaların hepsinde heartburn olmayabilir (5). TMC, nüfus tabanlı çalışmalarda haftada bir ya da fazla semptomları derecesine göre hafif, orta, ağır şeklinde gruplamıştır (3).

Amerika Birleşik Devletleri'nde (ABD) Gallup Organizasyonu (The Gallup Organization) tarafından ülke çapında yapılmış toplum temelli çalışmada, katılımcıların \%44'ü ayda bir kez heartburn tariflemiştir (6). Yine ABD'de yapılmış bir ankette katılımcıların \%22'si son bir ay içerisinde heartburn ve regürjtasyon tanımlarken, $\% 16^{\prime}$ sı sadece regürjitasyon tariflemiştir (5). 3 aylık süre içinde semptomatik reflüsü olan hastalar için Avrupa'daki prevalans ise \%5 ile \%15,5 arasındadır (7). GÖRH prevalansı, haftalık şikayetler baz alındığında batı dünyasında \%10 ile 20 iken Asya'da \%5 civarındadır $(8,9)$. Insidans ise batı dünyasında $\% 0,5^{\prime}$ dir. Hastalık her iki cinsiyeti neredeyse eşit oranda etkilese de komplikasyonları erkeklerde daha sık görülmektedir (10).

Türkiye'de yapılan GÖRH epidemiyolojik çalışmalarda ise Mayo soru formu ve GERD-Q formu kullanılmıştır (1113). Bor ve arkadaşlarının Mayo skoru kullanarak yaptığı çalışmada GÖRH prevalansı \%20 saptanmıştır (11). Türkiye'de Sivas ilinde yapılan çalışmada GÖRH prevalansı $\% 19,3$ (12), Bolu ilindeki prevalans \%12,5 (14), GÖRHEN çalışmasındaki prevalans ise $\% 22,8$ (15) idi. Mungan ve arkadaşlarının GERD-Q kullanarak Türk genel popülasyonunda yaptıkları çalışmada GÖRH prevalansı \%24,7 olarak saptanmışıı (13). Bu çalışmaların kümülatif değerlendirilmesinde ise GÖRH prevalansı \%23 olarak hesaplanmışı̧ır (16).

Konya İli merkez ilçelerinde yaptığımız anket çalışması ile buradaki popülasyonun GÖRH'den ne kadar ve ne şartlar altında etkilendiğini ortaya koymayı amaçladık. Bulduğumuz yerde GÖRH sıklığının yaş, cinsiyet, kilo, meslek, kronik hastalık birlikteliği, ekonomik durum gibi demografik özelliklere göre dağılımını inceledik. Bulunan prevalans ile Konya Illi Merkez ilçesinde günlük yaşamda aynı şikayetlerle gelen yüz hastanın kaçında ayıııcı tanıda GÖRH düşünülmesi intimalini de göstermiş olduk. Çalışma esnasında günlük yaşantısını önemli derecede etkileyen semp- tomlu hastaları ve hatta farklı tanı alanları birincil ve ikincil tedavisi için değerlendirme fırsatı bulduk.

\section{GEREÇ ve YÖNTEM}

Çalışmamız; Konya II Merkezinde adresleri önceden rastgele belirlenmiş kişilere reflü hastalığının ana belirtilerini, sıklı̆ını ve kişisel özelliklerini sorgulayan toplamda 39 soru içeren anketin yöneltilmesi sonucu yapılan kesitsel bir araştırmadır. Çalışma Haziran 2010-Ekim 2010 tarihleri arasında yapıımış olup 18-80 yaş arası gönüllü kişiler alınmıştır. Çalışma için, üniversitemizin ilaç dışı klinik araştırmalar değerlendirme komisyonunun 26 Mayıs 2010 tarih ve 2010/044 sayılı etik kurul onayı alınmıştır. GERDHRQL (Gastroeosophageal reflux disease-health related quality of life), RDQ (Reflux disease questionnaire), GERD Impact Scale (Gastroeosophageal reflux disease impact scale), CROME II (Combined ROME II questionnaire) gibi daha önceden kullanılmış anketler baz alınarak yeni bir anket yapıldı (Tablo 1). Ankette deneklerin yaş, cinsiyet, boy, kilo, medeni ve eğitim durumu, meslek, gelir gibi demografik özellikler yanı sıra alışkanlıklar, kronik hastalıklar gibi edinsel durumlar sorgulandı. Kullandığı ilaç ismini ya da grubunu bilen kişilerin kullandıkları ilaçlar da kayıt edildi.

İlk 5 soru GÖRH varlığını ortaya koyarken, 6, 7, 17, 22 numaralı sorular komplikasyonları irdelemekte; 1, 2, 3, 4, 5, $9,16,24$ numaralı sorular özofagus semptomları ile ilişkili iken $8,10,11,12,13,14,15,16,17,18,19,20,21,22$, 23, 24 numaralı sorular ise ekstra özofageal semptomları sorgulamakta idi. 17,18 ve 25 numaralı sorular hariç diğer tüm sorular 1'den 6'ya kadar semptomun şiddetine göre derecelendirildi (11) (Tablo 2).

Buna göre ilk 5 soruya $(4,5$ 'e ilaveten/veya 1, 2, 3 ) derece olarak 4, 5, 6 cevabını verenler reflü pozitif gruba dahil edildi. Dünyada benzer şekilde yapılmış çalışmalar değerlendirildi. Bunlardan rastgele olarak İspanya'da yapılmış olanın prevalans değeri alındı (12). \%90 güç, \pm 5 sapma ile bilinen bir değerden tahmini evrende örnek sayısı hesaplama tekniği ile 589 kişilik örnek sayısı oluşturuldu. Bu sayı düzeltme etkisi " 2 " ile çarpıldı $(589 \times 2=1188)$. Örnek büyüklüğü 1188 olarak bulundu. Bir toplumda 30 ayrı küme alınmasının heterojeniteyi temsil edeceği varsayıdı. Böylece öngörülen örnek büyüklüğü içinde toplamda 40 adet küme hacmi hesaplandı (1188/30 40). Her evde en az 2 erişkin olması muhtemel varsayılarak, her mahalleden 20 evin ankete alınması planlandı $(40 / 2=20) .20$ evde istenilen küme hacminin elde edilemediği durumda ev sayısı 21-22-23... şeklinde artııııdı. 
Tablo 1. Anket formu

\section{KONYA ILI MERKEZ ILÇESINDE REFLÜ PREVALANSI ANKETi}

\begin{tabular}{|c|c|c|c|c|c|c|c|c|c|c|}
\hline \multirow{2}{*}{\multicolumn{3}{|c|}{$\begin{array}{l}\text { Ad: } \\
\text { Eğitim durumu: }\end{array}$}} & Yaş: & Cinsiyet: & \multicolumn{4}{|c|}{ Medeni Hali: } & \multicolumn{2}{|c|}{ Uyruk } \\
\hline & & & Meslek: & & \multicolumn{6}{|c|}{ Aylık Gelir: } \\
\hline \multicolumn{2}{|c|}{ Boy } & Kilo & Sigara & Alkol & \multicolumn{6}{|l|}{ Spor } \\
\hline \multicolumn{2}{|c|}{ Kronik hastalık } & $\mathrm{KAH}$ & SVO & $\vdots \mathrm{DM}$ & \multicolumn{3}{|l|}{$\mathrm{KOAH}$} & \multicolumn{3}{|c|}{ Astım } \\
\hline \multicolumn{2}{|c|}{ KBY } & $\mathrm{KrKC}$ & RA & $\vdots O A$ & \multicolumn{3}{|c|}{ GUATR } & \multicolumn{3}{|c|}{ Migren } \\
\hline \multicolumn{2}{|c|}{ Depre } & Anemi & Kanser & $\vdots$ Hepatit & \multicolumn{3}{|c|}{ Gebelik } & & & \\
\hline \multicolumn{11}{|c|}{ İlaç } \\
\hline \multicolumn{5}{|c|}{ Son 3 ay içinde; ne sıklıkla } & ㅎ & $\underset{\substack{\pi \\
\frac{\pi}{\pi} \\
m}}{m}$ & 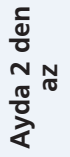 & $\begin{array}{l}N \\
\stackrel{N}{N} \\
N \\
\frac{\pi}{0} \\
\frac{\pi}{\alpha}\end{array}$ & 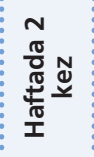 & $\begin{array}{l}: \frac{5}{0 ั 5} \\
\frac{1}{1}\end{array}$ \\
\hline 1 & \multicolumn{4}{|c|}{ Mide üzerinde yanma hissiniz oldu? } & 1 & 2 & 3 & 4 & 5 & 6 \\
\hline 2 & \multicolumn{4}{|c|}{ Gögüs kemiği arkasında ağrınız oldu? } & 1 & 2 & 3 & 4 & 5 & 6 \\
\hline 3 & \multicolumn{4}{|c|}{ Gögüs kemiği üzerinde yanma hissi oldu? } & 1 & 2 & 3 & 4 & 5 & 6 \\
\hline 4 & \multicolumn{4}{|c|}{ Mideden ağzınıza yiyecek gelmesi oldu? } & 1 & 2 & 3 & 4 & 5 & 6 \\
\hline 5 & \multicolumn{4}{|c|}{ Ağzınıza acı, tuzlu su gelmesi oldu? } & 1 & 2 & 3 & 4 & 5 & 6 \\
\hline 6 & \multicolumn{4}{|c|}{ Ağrılı yutmanız oldu? } & 1 & 2 & 3 & 4 & 5 & 6 \\
\hline 7 & \multicolumn{4}{|c|}{ Yutma güçlüğünüz oldu? } & 1 & 2 & 3 & 4 & 5 & 6 \\
\hline 8 & \multicolumn{4}{|c|}{ Öksürük, gece öksürüğü oldu? } & 1 & 2 & 3 & 4 & 5 & 6 \\
\hline 9 & \multicolumn{4}{|c|}{ Bulantı, kusma oldu? } & 1 & 2 & 3 & 4 & 5 & 6 \\
\hline 10 & \multicolumn{4}{|c|}{ Nefeste ötme, Islık oldu? } & 1 & 2 & 3 & 4 & 5 & 6 \\
\hline 11 & \multicolumn{4}{|c|}{ Ses kısıklığınız oldu? } & 1 & 2 & 3 & 4 & 5 & 6 \\
\hline 12 & Gıcıklanma & רוz oldu? & & & 1 & 2 & 3 & 4 & 5 & 6 \\
\hline 13 & Ağız kokur & uz oldu? & & & 1 & 2 & 3 & 4 & 5 & 6 \\
\hline 14 & Boğazda a & tat hissettiniz? & & & 1 & 2 & 3 & 4 & 5 & 6 \\
\hline 15 & Boğazda d & iğümlenme hiss & & & 1 & 2 & 3 & 4 & 5 & 6 \\
\hline 16 & Salya artışı & IIz oldu? & & & 1 & 2 & 3 & 4 & 5 & 6 \\
\hline 17 & Kilo verdin & & & & & EVET & & & HAYIR & \\
\hline 18 & Kilo aldınız & & & & & EVET & & & HAYIR & \\
\hline 19 & Uykunuz b & lündü? & & & 1 & 2 & 3 & 4 & 5 & 6 \\
\hline 20 & Salya artışı & Iz oldu? & & & 1 & 2 & 3 & 4 & 5 & 6 \\
\hline 21 & Nefes darlı & ýnız oldu? & & & 1 & 2 & 3 & 4 & 5 & 6 \\
\hline 22 & Sinuzit old & & & & 1 & 2 & 3 & 4 & 5 & 6 \\
\hline 23 & Geniz akın & Inız oldu? & & & 1 & 2 & 3 & 4 & 5 & 6 \\
\hline 24 & Şişkinlik, g & z hissettiniz? & & & 1 & 2 & 3 & 4 & 5 & 6 \\
\hline 25 & Tedavi aldı & II mı? & & & & EVET & & & HAYIR & \\
\hline
\end{tabular}


Tablo 2. Anket sorularının derecelendirilmesi

\begin{tabular}{|c|c|c|c|c|c|}
\hline $\mathbf{1}$ & $\mathbf{2}$ & $\mathbf{3}$ & $\mathbf{4}$ & $\mathbf{5}$ & $\mathbf{6}$ \\
\hline Yok & 3 ayda 1 & Ayda 2'den az & Ayda 2 kez & Haftada 2 kez & Hergün \\
\hline
\end{tabular}

Mahalle bazında nüfusa ağırlıklı küme örnekleme yöntemiyle kümelerin hangi mahallelerden alınacağına karar verildi. II sağlık müdürlüğünden alınan ev halkı tespit fişi (ETF) kayıtlarında merkez ilçelere bağlı köyler iptal edilerek Konya ili merkez ilçelerinde (Selçuklu, Meram, Karatay) mahalle niteliğinde toplamda 251 yerleşim yeri seçildi. Seçilen yerleşim yerlerinin toplam nüfusu 950.152 idi. Bu nüfus saptanılan küme sayısına bölündü $(950.152 / 30=31.672)$. Rastgele sayılar tablosundan 5 rakamlı sayılar sınıfından rastgele bir sayı seçildi (24.323). Bu sayının içinde olduğu küme ilk küme olarak belirlendi. Bu seçilen sayı üzerine 31.672 eklenerek 2. kümenin başlayacağı mahalle, eklenilerek bulunan sayının üzerine tekrar 31.672 eklenerek 3. Kümenin başlayacağı nüfusun olduğu mahalle bulundu. Bu şekilde 30 küme ve mahalle seçimleri yapıldı. Böylece nüfusa ağırlıklı olarak her 31.672 kişide 1 küme oluşturulmuş oldu. Belirlenen 30 mahalleye 20 sağlık ocağının hizmet verdiği görüldü. İlgili sağlık ocaklarının telefon numaraları il sağlık müdürlüğünden temin edildi. Her bir sağlık ocağı aranarak seçilen mahalleye bakan ebe ve/veya hemşire ile görüşüldü. ETF kartlarından rastgele birini seçmesi ve seçtiği adresi bildirmesi istenildi. Alınan adres seçilen mahalle için başlangıç noktası kabul edildi. Anket sorgulamasına bu noktadan itibaren 20 hane/40 kişi oluncaya kadar aynı sokakta, sokağın sonlanması durumunda saat yönünde olan ilk sokaktan devam edildi.

18 yaşından büyük 80 yaşından küçük gönüllü kişiler ankete alındı. Her evden 1. dereceden akraba olan en çok bir kişi alındı. Son 1 senedir Konya II Merkezinde oturmayan, ankete katılmayı reddeden, 18 yaşından küçük olan kişiler ankete alınmadı. Anket esnasında gerek görüldügünde alarm semptomlar da soruldu. Semptomatik olan hastalar fakültemiz gastroenteroloji polikliniğine davet edildi.

Haziran-Ekim 2011 tarihleri arasında yapılan çalışmada hedeflenen 1188 anket formu için ankete katılmama isteği, yanlış cevap verme gibi nedenlerden dolayı yaklaşık olarak 2000 kişi ile görüşüldü (geri dönüş oranı: \%59). Alınan kişisel bilgilerin kesinlikle paylaşılmayacağı her deneğe anket öncesinde söylenildi. Önceden belirlenen bir hanede 2 kişi bulma intimalini artırmak için hafta sonları ve mesai saatleri dışında anket yapıldı. Birbirine komşu olan mahalleler anketin duyulma ihtimalini düşürmek için ardışık olarak tarandı. Bazı mahallelerde ankete dahil edilme koşuluna uyan ve önceden belirlenen rastgele adres üzerine denk gelen işyerlerinde de anket uygulaması yapıldı.

\section{İstatistiksel Analiz}

Anket verileri SPSS (Statistical Packace For Social Science) 15.0 versiyon istatistik paket programı kullanılarak değerlendirildi. Verilerinin yorumlanmasında Selçuk Üniversitesi Meram Tıp Fakültesi Tıbbi İstatistik Bilim Dalı́ndan destek alındı. Hastaların yaşı, ortalama \pm standart sapma, diğer değişkenler aksi belirtilmedikçe ortalama \pm ortalamanın standart hatası şeklinde ifade edildi. Sürekli verilerin bağıntısını belirlemek için "Pearson Korelasyon Katsayısı" kullanıldı. Tüm $P$ değerleri için önemlilik düzeyi $P<0.05$ kabul edildi. Kategorik değişkenlerde reflü varlı̆ının derecesi ile ilişkisi için "backward" yöntemi uygulandı. Yöneltilen soruların reflülü hastalarla olan ilişkisini ortaya koyabilmek için "regresyon analizi" yapıldı.

\section{BULGULAR}

Anket çalışmasında 581'i kadın (\%48.9), 607'si erkek (\%51.1) toplam 1188 kişi ile görüşüldü. Yaş ortalaması $41.34 \pm 12.8 \mathrm{yll}$, ortanca yaş 40 idi. Deneklerin 1002 'si (\%84.3) evli iken 186'sı (\%15.7) bekar ya da dul idi.

502 kişi (\%42.2) ilköğretim mezunu iken, 397'si (\%33.4) lise, 289'u (\%24.3) üniversite mezunu idi. Aylık gelir beyanının yaklaşık \%60'a yakını 1-2 bin lira arasında idi.

Kilogram olarak alınan ağırlık ve metre cinsinden alınan boy ölçüleri vücut kütle indeksi (VKI) $(\mathrm{kg} / \mathrm{m} 2)$ oranından hesaplandı. Buna göre ankete katılanların sadece \%32.6'sı normal kilolu (VKi=18.5-24.9), \%57.9'u VKi=2529.9, \%9, $5^{\prime} u$ ise $V K I>30$ idi. Veriler değerlendirilirken santimetre olarak boy ve kilogram olarak ağırlık değerleri kendi içlerinde gruplandırılmıştı. Ancak VKI hesaplanırken ankete katılanların bilgileri direk hesaplanmıştı. Böylece verinin kendi grubu içinde düşük veya yüksek bir bölümde olup da VKi hesaplanmasında yanlışlıkla yüksek ya da düşük çıkmasının önüne geçilmiş olundu.

Katılımcıların \%31'i sigara kullanırken, \%10'a yakını spor yapabiliyordu. \%29.7'sinde dispeptik yakınmalar yapabilecek ilaçların kullanıldığı en az bir kronik hastalık mevcuttu (Tablo 3). 


\begin{tabular}{|l|c|c|c|c|}
\hline & Tablo 3. Eşlik eden kronik hastalıklar \\
\hline & 847 & 71,3 & 71,3 & 71,3 \\
\hline Yok & 72 & 6,1 & 6,1 & 77,4 \\
\hline Hipertansiyon & 61 & 5,1 & 5,1 & 82,5 \\
\hline Diabetes mellitus & 29 & 2,4 & 2,4 & 84,9 \\
\hline Kroner arter hastalığı & 29 & $\begin{array}{c}\text { Geçlanmış } \\
\text { yüzde }\end{array}$ \\
\hline Kronik obstrüktif & 12 & 1,0 & 1,0 & 85,9 \\
\hline akciğer hastalığı & 30 & 2,5 & 2,5 & 88,5 \\
\hline Hipotroidi & 16 & 1,3 & 1,3 & 89,8 \\
\hline Gebelik & 20 & 1,7 & 1,7 & 91,5 \\
\hline Romatolojik hastalık & 101 & 8,5 & 8,5 & 100,0 \\
\hline Diğer & 1188 & 100,0 & 100,0 & \\
\hline Toplam & & &
\end{tabular}

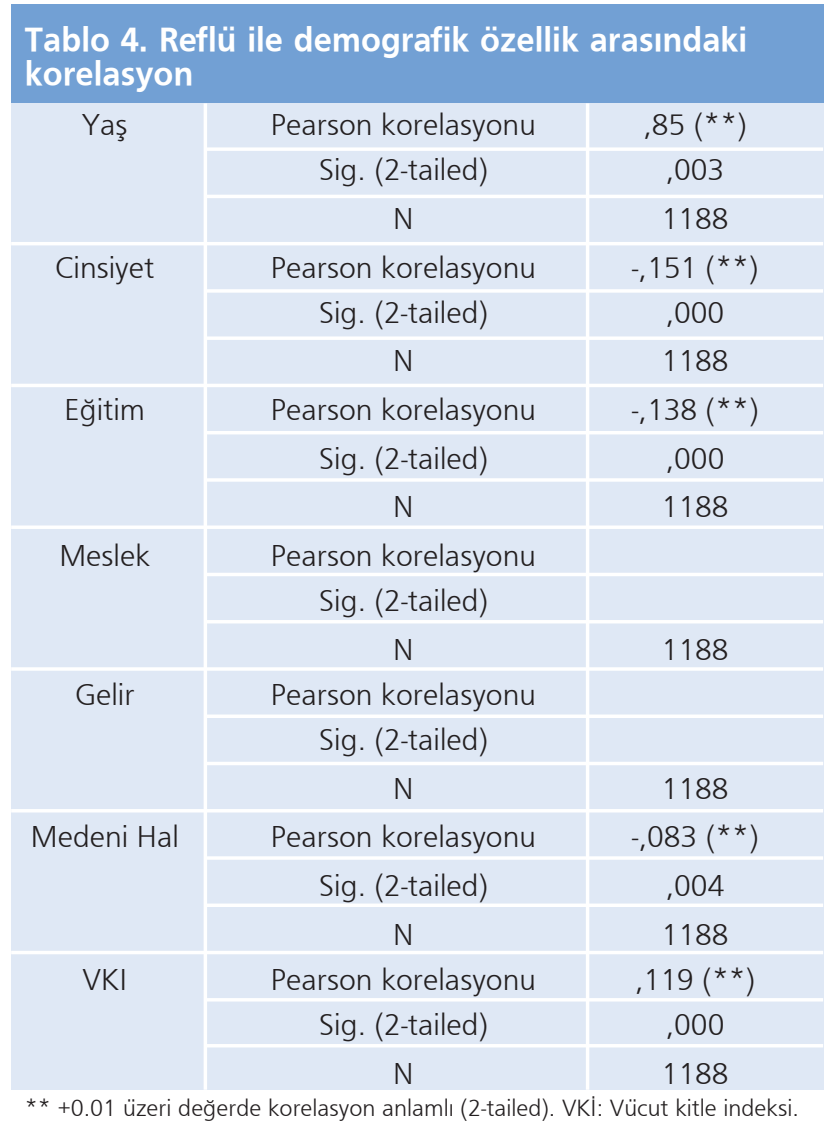

Hastalığı irdeleyen son 25 soruya bakıldığında reflü tanısı için 3, 4, 5 numaralı sorulara cevaben sıklık olarak 4, 5, 6 cevabını verenler reflü hastalığı var olarak kabul edildi $(3,11)$. Sorular değerlendirildiğinde kriterlere uyan cevap derecesine göre bulunan gastroözofageal reflü prevelansı \%10.9 idi (Şekil 1).

Ankete göre reflüsü saptanan katılımcıların demografik özelliklerine göre irdelenmesinde ise şu sonuçlara ulaşıldı; cinsiyet, medeni hal, eğitim durumu, meslek ve gelir durumu reflü ile korelasyon göstermezken artan yaş ve VKi anlamlı şekilde koreleydi (Tablo 4).

Reflüsü saptanılanların verdiği cevaplarla reflü pozitifliğinin korelasyonuna bakıldığında ise $6,7,8,10,11,13,14$, 15, 19, 21 ve 22 numaralı sorular kısmen; 1, 2, 9, 12, 18, 20, 23 ve 24 numaralı sorular orta derecede; 3, 4, 5 ve 16 numaralı sorular yüksek derecede ilişkili idi. Verilen "reflü yok" cevabına (derece 1) göre sıklık açısından değerlendirme yapıldığında soru 3 için 2,4; soru 4 için 12,3; soru 5 için 2,4; soru 16 için 1,6 Odds oranı tespit edildi. Buna göre retrosternal yanma hissinin bulunması, reflüsü olmayanlara göre riski 2,4 kat, ağıza mide içeriğinin gelmesi (soru 4) 12,3 kat, ağıza acı tuzlu sıvı gelmesi (soru 5) 2.4 kat ve salya artışının olması (soru 16) 1,6 kat artırmakta idi (Tablo 5).

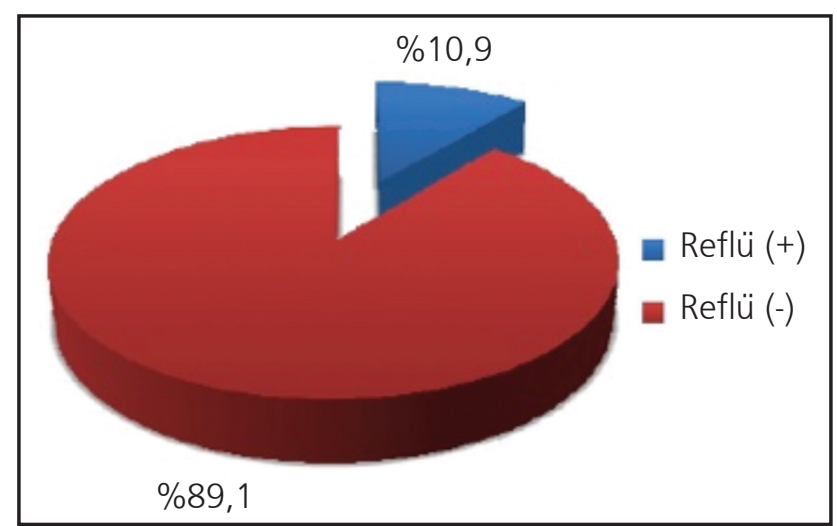

Şekil 1. Gastroözofageal reflü prevalansı

Tablo 5. Reflü ile ilişkili sorularda Odds oranları

\begin{tabular}{|l|c|c|c|c|c|c|c|c|}
\hline & B & S.E. & Wald & df & Sig. & Exp(B) & \multicolumn{3}{|c|}{$\begin{array}{c}\text { 95,0\% C.I.for } \\
\text { EXP(B) }\end{array}$} \\
\hline & Alt & Üst & Alt & Üst & Alt & Üst & Alt & Üst \\
\hline Soru 3 &, 902 &, 173 & 27,037 & 1 &, 000 & 2,465 & 1,754 & 3,463 \\
\hline Soru 4 & 2,515 &, 283 & 79,001 & 1 &, 000 & 12,365 & 7,102 & 21,530 \\
\hline Soru 5 &, 882 &, 173 & 26,121 & 1 &, 000 & 2,415 & 1,722 & 3,387 \\
\hline Soru 16 &, 477 &, 232 & 4,225 & 1 &, 000 & 1,611 & 1,022 & 2,540 \\
\hline Constant & $-12,563$ & 1,206 & 108,439 & 1 &, 000 &, 000 & & \\
\end{tabular}


Daha önceden tedavi alınıp alınmadığını sorgulayan 25 numaralı soru ile reflünün ilişkisi tedavi alanlar lehine oldukça anlamlıydı $(P C=0,456, p<0,05)$. Kadınların $\% 15$ 'inde reflü pozitif bulunurken erkeklerde bu oran $\% 6^{\prime}$ da kalmakta; evli nüfusun \%11'inde reflü var iken bekar ya da dulların \%4'ünde; ilköğretim mezunlarının $\% 16$ 'sında reflü saptanmışken lise mezunlarının \%7'sinde, üniversite mezunlarının $\% 5$ 'inde; normal ya da kilolu nüfusun $\% 8$ 'inde reflü varken obezlerde oran \%24'lere çıkmaktaydı (Tablo 6).

Sigara, alkol ve sporla reflü arasındaki ilişki negatifti (PC $=-0,104, P C=-0,030$ ve PC=-0,077, sırasıyla). Ancak bu korelasyon bir neden sonuç ilişkisi değildi.

\begin{tabular}{|c|c|c|c|}
\hline & & Reflüsü Olan & Reflüsü Olmayan \\
\hline \multirow{2}{*}{ Cinsiyet } & Kadın & $91(\% 15,7)$ & $490(\% 84,3)$ \\
\hline & Erkek & $38(\% 6,3)$ & $569(\% 93,7)$ \\
\hline \multirow{2}{*}{ Medeni hal } & Evli & $120(\% 11,2)$ & $882(\% 88,8)$ \\
\hline & Bekar & $9(\% 4,9)$ & $177(\% 95,1)$ \\
\hline \multirow{4}{*}{$\begin{array}{l}\text { Öğrenim } \\
\text { Durumu }\end{array}$} & Ilkokul & $45(\% 16,3)$ & $232(\% 83,7)$ \\
\hline & Ortaokul & $36(\% 16)$ & $189(\% 84)$ \\
\hline & Lise & $31(\% 7,8)$ & $366(\% 92,2)$ \\
\hline & Üniversite & $17(\% 5,9)$ & $272(\% 94,1)$ \\
\hline \multirow{3}{*}{$\mathrm{VKI} \mathrm{kg} / \mathrm{m}^{2}$} & $18,5-24,9$ & $31(\% 8,1)$ & $356(\% 91,9)$ \\
\hline & $25-29,9$ & $70(\% 10,2)$ & $618(\% 89,8)$ \\
\hline & $>30$ & $28(\% 24,8)$ & $85(\% 75,2)$ \\
\hline
\end{tabular}

VKi: Vücut kitle indeksi.

\section{TARTISSMA}

GÖRH sık rastlanılan bir sağlık sorunudur. Fizyolojik olarak bazı insanlarda reflüye yatkınlık normal nüfusa göre sık olsa da demografik özellikler de reflü sıklığının artmasında çok önemli rol oynarlar. Hastalığın topluma verdiği zarar farklı boyutlarda kendini gösterebilmektedir. Kimi hastada sadece yemek sonrası regürjitasyon, rahatsızlık hissi şeklinde kendini gösterirken kimisinde de tanı alabilecek bir karsinom olarak ortaya çıkabilir. Hastalığın tanısında ileri teknolojik aletlerden ziyade sadece anamnezin yüksek olasılıkla tanıyı koydurması hastalık için kesinlikle bir avantajdır. Bu avantajı kullanarak yaşadığımız çevrenin reflü prevalansını belirlemek için semptomlara ve komplikasyonlara yönelik hazırladığımız anket vasıtasıyla yaptığımız çalışmada \%11'e yakın prevalans elde ettik. Bizim ilimizdeki reflü prevalansı; Türkiye'de yapılan diğer çalışmaların kümülatif değerlendirilmesinden ortaya çıkan GÖRH prevalansı \%23 olarak hesaplanmıştır (16) ve buna göre düşüktür. Konya il merkezimizdeki GÖRH prevalansı \%10,9 olup, Bolu ilindeki prevalansa $(\% 12,5)$ benzerlik göstermiştir (14).

Hastalık için uzun yıllardır farklı ülkelerde prevalans çaışması yapılmış olup, birçok demografik özelliklere göre tasnif yapılmıştır. Modern yaşam, obezite, ekonomik durum, yaşlı olmak hastalıkla daha fazla karşılaşma intimalini arttırır gibi görünse de bölgesel çalışmalar oldukça değişik sonuçlar sunmaktadırlar.

Yetişkin nüfusu içine alacak şekilde Almanya'da yapılmış benzer bir çalışmada 18-79 yaş arası 7124 kişi beslenme, hayat kalitesi, demografik özellikler açısından araştırılmış, \%25 hafif, \%14 orta ve \%4 şiddetli reflü prevalansı bulunmuştur (13). Yaş dikkate alınmadığında kadın-erkek oranı benzer bulunmuş; 60-70'li yaşlarda ise bayanlarda şiddetli reflü yakınmaları daha fazla bulunmuştur. Çalışmada reflü prevalansı yaşla son derece ilişkili bulunmuş, sosyoekonomik durum, VKi, sigara içimi hakkında yeterli görüş belirtilmemiş, sadece reflü semptomları üzerinden yürütülmüş ekstraözafageal semptom ve komplikasyonlar hakkında soru sorulmamıştır. VKi ile anlamlı korelasyonu gösterdiğimiz çalışmada tüm sorular araştırma görevlisi tarafından yönlendirilmiş olup hastalığı sorgulayan sorular yanında, özafagus dışı semptomları sorgulayan sorular ve komplikasyonları sorgulayan sorular da vardı. Çalışmamızda da reflüsü olan hastaların yaşa bağlı şikayet derecesinde artış vardı.

Yine Almanya'da reflüsü olan hastalarda disfaji prevalansını inceleyen bir diğer çalışmada 268 kişiye yöneltilen anket sorularının değerlendirilmesi neticesinde \%34 reflü prevalansı bulunmuştur (14). Köln şehrinde en az 1 yıldan fazla ikamet etmiş kişilerle posta yoluyla irtibat kurulmuştur. Erkeklerin daha fazla şikayetlerinin bulunduğu (\%36) çalışmada hastaların \%90'ının aylık, \%25'inin haftada ikiden fazla, \%9'unun da günlük semptomlarının olduğu ayrıca \%45'inin de reflü nedeniyle ilaç aldığı saptanmıştır. Çalışmamızda reflü nedeniyle ilaç kullanma oranı \%13,8 idi. Çalışmada prevalans yüzdesini arttırıcı etken olarak reflünün semptomatolojisinin iyi irdelenmesi, yapılan görüşme sayısının çokluğu ve dönüş oranından bahsedilmiştir. Bizim çalışmamıza Konya merkez ilçeleri nüfusunu temsil edebilecek en yüksek oranda örnek sayısı alınmış, önceden belirlenen adrese gidilip anket yapıldığından geri dönüş oranı \%59 olmuştur.

Amerika'da iyi örnekleme yapılmış GÖRH ve spastik kolon birlikteliğini sorgulayan bir diğer çalışmada 2298 kişi ile elektronik posta yolu ile anket yapılmış; erkeklerde \%15, kadınlarda \%14 reflü prevalansı bulunmuştur (15). Çalışmada reflü derece skorlaması süre olarak 1 sene üzerin- 
den yapılmış, hastalık semptomları olan kişiler reflünün olduğu gruba alınmıştır. Değerlendirmede erkek-kadın, VKi, eğitim durumu, medeni hali ve yaşlar arası fark saptanılmamıştır. Çalışmamızda son 3 aylık süre zarfında sorgulama yapılmış, ayda 2 ve daha fazla şikayeti olan kişiler reflülü olarak kabul edilmiştir. Çalışmamızın yapıdığı zaman aralığı yaz dönemine rastladığından bulunan rakamlar da mevsimsel özellik taşımaktadır. Bu nedenle senelik reflü prevalansını göstermemektedir. Çalışmamıza neredeyse eşit sayıda kadın ve erkek katılımcı alınmışır. Bizim bulduğumuz değerlere göre de cinsiyet, eğitim durumu ve medeni hal reflü ile korelasyon göstermezken yaş ve VKI yakın korelasyon göstermektedir.

Amerika'da azınlıklar üzerine yapılmış bir çalışmada ise haftalık ortalama \%26,2 gibi yüksek prevalans bulunmuştur (16). Kafkas, İspanyol, Afrika ve Asya göçmenlerinde yapılmış araştırmada hastaların \%32,9'u kilolu, \%31,7'si obez bulunmuştur. VKi, yaş ve düşük sosyoekonomik durum ile korele olan reflü hastalarından Afrika ve İspanyol kökenlilerde reflü prevalansı daha fazla bulunmuştur. Burada ilginç olan söz konusu ırkların kendi ülkelerinde yapılan benzer çalışmalarda reflü prevalanslarının daha az olmasıydı. Batı toplumlarında prevalansın artmış görülmesini destekler nitelikte olan bu durumun nedeni yapılacak büyük ve detaylı çalışmalarla ortaya konulabilecektir. Ancak anket sonrası verilen hediye çekinin de prevalansı yüksek çıkartma ihtimali unutulmamalıdır. Bizim çalışmamızda kilolu kişiler (VKi 25-30 arası) \%57,9, obezler ise $\% 9,5$ oranında idi. Sosyoekonomik farklılık yoktu. Lakin çalışmamızda etnik grup detayı gözetilmemişti. Arjantin'in farklı bölgelerinden toplamda 839 kişi ile anket çaIışması yapılmış; yıllık reflü semptomları prevalansı $\% 23$, GÖRH prevalansı \% 11,9 olarak rapor edilmiştir (17). Emekli olmuş yaşılıar ve aktif çalışanların seçildiği bu çalışmada, GERQ anketi semptom sıklı̆̆ bir sene ile her gün arasında olacak şekilde yeniden düzenlenerek 32 soruluk yeni bir anket yapılmış, değerlendirme sonrası aylık $\% 16,8$, haftalık $\% 10,3$ ve günlük $\% 3,1$ reflü prevalansı bulunmuştur. Yine değerlendirmelerinde cinsiyet açısından farklılık bulamazken yaş ve VKi ile belirgin korelasyon bulmuşlardır. Arjantin'de yapılan bu çalışma yeni düzenlenmiş bir anketin ülkenin farkı özelliklerini sorgulayacak olması bakımından gerekliliğini savunmuştur. Ancak Avrupa ve Amerika kıtaları arasındaki belirgin reflü farklıı̆ının olmasının bir nedeninin de farklı özellikte anket kullanımına bağı olabileceğini de belirtmiştir. Anketimizdeki sorular daha önceden kullanılmış 4 farklı anketin yeniden düzenlenmesiyle yapılmıştır. Tahmin edilen birçok faktöre rağmen Avrupa ile Amerika arasındaki bu reflü prevalans farklıı̆ı temelde halen belirsizdir (17).
Kalixanda çalışmasında, İsveç'te yaklaşık olarak 3 bin katılımcı ile anket çalışması yapılmış, bunlardan rastgele bin tanesine özofagogastroskopi yapılmışır (18). Haftalık prevalans \%14 bulunurken, \%15,4 özofajit saptanmıştır. Çalışmada ASQ kullanıımış olup prevalansın bu denli yüksek çıkmasının sebebi olabilir. ASQ üst ve alt abdominal semptomları beraber içeren sorulara sahiptir. Bizim çalı̧mamızda \%90 güç ile yaşadığımı çevreyi temsil edebilecek optimal örnek sayısı tespit edilmiş, anket sorularının tamamen reflü semptomatolojisi ve komplikasyonlarını içermesine dikkat edilmiştir.

Avustralya'da yapılmış 2973 kişiden oluşan anket çalışmasında ise reflü ve antisekretuvar ilaç kullanımı arasındaki ilişki öne çıkarılmıştır (19). Bulunan reflü prevalansı $\% 12,4$ iken, reflü semptomları nedeniyle ilaç kullanan hasta oranı \%16,9 olarak rapor edilmiştir. Bizim çalışmamızda semptom nedeniyle ya da tedavi amaçlı ilaç kullananların oranı \%13,8 idi. Antisekretuvar ilaç kullanımının bu derece yüksek olması reflü sıkığının batı ülkelerinde artış sıklığııın indirek bir göstergesi olabilmektedir. Yüzde 59 geri dönüşü olan bir diğer çalışmada 50 soruluk bir anket hazırlanmış, 2231 kişinin \%21'inde GÖRH semptomu tariflenmiştir (20). Hastaların kişisel özelliklerine bakıldığında VKI'i ve irritabl barsak sendromu (IBS), dispepsi gibi bazı ek hastalıklar ile pozitif korelasyon bulunurken yaş ve cinsiyet ile korelasyon saptanılmamıştır. Diğer çalışmalarda saptanılmayan bir bulgu ise GÖRH etiyolojisinde genetik faktörlerin de bulunabilecek olması intimaliydi. Çalışmada reflüsü olan hastaların birinci derece yakınlarında da reflü sıklığı artmış olarak bulunmuştur. Oysa yaptığımız çalışmada olduğundan fazla çıkabilecek prevalansı engellemek için bu intimali gözeterek birinci dereceden yakınlığı olan kişilerle anket görüşmesi yapıımamıştı. Fazla alkol tüketiminin reflü ile ilişkili bulunduğu çalışmada, bunun sebebi olarak kronik alkol tüketiminin neden olduğu nöropatik hasar sorumlu tutulmuştur. Bizim bulduğumuz alkol tüketimi \%3 idi, ve reflülü hastalarla korelasyonu yoktu (PC -0,030).

İran'da yapılmış bir başka çalışmada \%33 gibi oldukça yüksek bir reflü prevalansı bulunmuştur (21). Ancak bu çalışmada örnek sayısı nispeten az tutulmuş ve göçebeler üzerinde yapılmıştır. Yine de bulunan sonuçlar ilginçtir. Obez ya da olmayan kişiler ve cinsiyet arasında istatistiksel fark bulunamamış, risk faktörleri arasında özellikle meyve ve sebze tüketiminin reflüyü arttırmış olduğu görülmüştür. Çalışmaya göre meyve ve sebze tüketimi reflüyü 2,7 kat artırmakta idi (OR:2,7). Bu durum yenilen yiyeceğin niteliği yanında araştırmanın yapıldığı toplumun ekonomik durumu ve alıskanlıkları ile daha alakalı gibi gözükmektedir. Çalışmamızda VKI artışının reflüyü 
arttırdığı gösterilmiş; yeme alışkanlıkları ve etnik kökene ait soruların olmaması nedeniyle VKI'nin yüksek olduğu bölgemizde daha detaylı sonuçlar çıkarılamamıştır (22). Ancak çalışmamızın amaçları arasında yaşadığımız çevrenin prevalansını bulacak olmamız etnik kökeni sorgulamamamızın nedeni olabilir. Ayrıca belirtilen çalışmada yasak olmasından dolayı alkol sorgulaması yapılmamıştır. Bu nedenle olası alkol alımının etkileyeceği dispeptik yakınmalar nedeniyle prevalans yüksek bulunmuş olabilir.

Diğer bir Ortadoğu ülkesi olan İsrail'de de benzer bir araştırma yapılmış; haftalık reflü prevalansı \%12,5 olarak bulunmuştur (23). Telefon konuşması şeklinde yapılan ankette toplamda 2027 görüşme yapılmış, değerlendirmede ise diğer çalışmalar gibi cinsiyet farkı saptanmamıştır. Çalışmada bazı açılardan eksik sorgulama yapıldığı kabul edilse de ilginç bazı saptamalar da belirtmiştir. Sosyoekonomik durum ile reflü diskordansı mevcuttu. Bu sonucu destekleyen diğer çalışmalarda da söylenildiği üzere sosyoekonomik olarak düşük kesimde sigara ve normal kiloyu aşma ihtimali daha fazla idi. Yine bu çalışmada şikayetlerden dolayı ilaç alan, almayan kesimin yanında bazı yöntemler ile reflü semptomlarını ortadan kaldırmaya çalışan \%22,5'luk bir grup daha vardı. İçerik olarak doğal bitki karışımlarından ve geleneksel bazı yöntemlerden oluşmakta idi. Çalışmanın bir uzman tarafından yapılmaması, ekstra özofageal semptomların sorgulanmamış olması ve birçok çalışmada ispatlanmış VKİ-reflü ilişkisine rağmen VKì hesaplanılmamış olması eksik tarafları idi. Bu nedenle her ne kadar ortalama bir reflü prevalansı rakamı bulunmuş olsa da bizim çalışmamıdaki şartlar oluşturulmamış, böylece olası diğer nedenler dışlanamamış olabilir.

Akdeniz kıyısında yapılan bir çalışmada ise haftalık prevalans \%15 olarak bulunmuştur (12). Araştırmada bizim anketimize benzer demografik özelliklerden sadece VKI ile reflü korelasyonu bildirilmiştir. Çalışmadaki yaş aralığında alkol alımının \%100'e yaklaştığı halde reflü ile ilişkilendirilmemiş olması ilginçtir. Daha önceki çalışmalarda risk faktörü olarak bahsedilmemiş hiperkolesteroleminin bu çalışmada ilişkili bulunmuş olması dikkat çekicidir. Ancak bu faktörü çoğu zaman obeziteden ayırmak mümkün değildir. Örnekleme modeli, benzer demografik özellikler ve ortalama reflü prevalansı nedeniyle anketimizin sayısal niteliklerini oluştururken bu çalışmadan esinlendik.

Avrupa, Orta Doğu ve Amerika'da reflü prevalansı \%10-20 arasında iken Asya'daki veriler prevalansın \%2-7 arasında olduğunu göstermektedir. Ancak Asya'da rakamsal olarak az gibi görülen prevalansın sanıldığından daha fazla olduğu endoskopik çalışmalarla gösterilmiştir (24).
Değişik ülkelerdeki reflü prevalansı farklıı̆ğının sebeplerinden bazıları da semptom tanımlama yanlışlığı ve tanıda standardizasyon yapılmaması olabilir. Bizce sadece semptomları olan hastaların değil; komplikasyonu olan hastaların da prevalansa dahil edilmesi gerekmektedir. Öyle ki bazı ülkelerde katılımcılara birebir çevrilmiş anket soruları sorulmuş, katılımcılar özellikle "heartburn" ifadesini tam olarak anlayamadan olumsuz yönde cevap vermişlerdir. Hatta kimi Uzakdoğu dillerinde "heartburn" teriminin tam olarak karşılı̆̆ı yoktur.

Japonya'da rutin kontrole gelen kişilerde yapılmış bir çalışmada haftalık \%4,6, aylık \%12,8, ortalama $\% 6,6$ oranında prevalans bulunmuştur (11). Cinsiyet farklılığı bulunamayan değerlendirmenin tümünün belirli şirketlerde ve çalışanlar üzerinde yapılmış olması tüm nüfusa genellenemeyecek olmasını düşündürmektedir.

Tüm nüfusa genellenebilecek bir örnek sayısı ile yapılan diğer bir çalışmada ise prevalans aylık \%20 olarak gösterilmiştir (25). Anketin katılımcı sayısının çok olmasına karşın anket sorularının detaysız, endoskopi kontrolüne gelen kişilerde yapılması ve üç sorudan ibaret olması topluma uyarlanabilirliğini şüphede bırakır gibiydi. Yine de seksen bin civarında kişinin anketinin yapılması ile yetinilmeyip endoskopisinin de yapılması güvenilirliğini arttıran etkenlerdir. Sonuçta hiatal hernili ve ülserli hastalarda cinsiyet gözetmeksizin prevalansın fazla olduğu saptanmıştır.

Kore'den gelen prevalans yüzdesi ise haftalık \%3,5'dir (26). Yaş, cinsiyet, VKi, sosyoekonomik durumla korelasyon bulunmamıştır. Doğu-Batı arasındaki reflü prevalans farkına dair genetik ve Helicobacter pylori (H. pylori) etkisinin bahsedildiği çalışmada H. pylori koruyucu bir faktör olarak sunulmuştur. Oysa çalışmada H. pylori'ye ait veri olmamasına rağmen $H$. pylori'nin Güney Asya ve siyah ırkta fazla olması da istatiksel olarak verileri destekler niteliktedir.

Son olarak ülkemizde birinci basamak sağlık kuruluşlarına başvuran hastalarda yapılmış bir prevalans çalışmasında dispeptik şikayetleri olan ve olmayan hastalar ankete tabi tutulmuş, dispeptik şikayetlerle gelen hastalarda \%38,3 reflü tanısı konulurken, diğer grupta \%25,4 gibi oldukça yüksek bir rakam bulunmuştur (27). Burada anketin doktor tarafından yapılması, dolayısıyla tanının doktor tarafından konulması dikkat çekerken, sağlık kurumuna zaten herhangi bir rahatsızlık nedeniyle başvuran hastalarda yüksek oranda reflü prevalansı bulunması kabullenilebilecek bir durumdur. Erkek/kadın oranı 2,25 olarak bulunmuştur. Bizim çalışmamızda anket soruları araştırma görevlisi tarafından yöneltilirken, değerlendirme sonrası reflülü hastalarda erkek kadın oranı eşit olarak çıkmıştır. 
Referansı verilen çalışmanın şikayeti olan hastalar üzerinde yapılmış olması nedeniyle toplumdaki gerçek prevalansı yansıtmayacak olması bilinmelidir.

Sonuçta; yapılan tüm çalışmalarda ortak olarak GÖRH ile ilişkili durumlar kilo alımı, yaş, beslenme şekli, sigara-alkol kullanımı gibi literatürde zaten hastalığın etiyolojisinde bahsedilen sebepleri onaylamaktadır. Diyetteki yağ oranının batıya gidildikçe artması, hastalığın doğu ülkelerinde daha az görülmesini açıklayabilir. Hemen hemen bütün çalışmalarda zannedilenin aksine kadınlarda reflü prevalansı erkeklerdekine eşit bulunmuştur. Ancak yaş artışı ile beraber kadınlar aleyhine bir artış da söz konusu gibi görülmektedir.

Yapılan çalışmaların tamamında batı-doğu karşılaştırması yapııırken kuzey-güney kıyaslaması yapılmamıştır. Sıcaklık ve iklim değişikliklerinin de etiyolojide yer alabilmesi adına bu konuda da araştırma yapılması faydalı olacaktır.

Yine bütün çalışmalarda özellikle analjezik olarak non-steroid antiinflamatuvarların (NSAii) ne kadar fazla kullanıldığı rakamsal olarak da ifade edilmiştir. Etiyolojideki yeri

\section{KAYNAKLAR}

1. El-Serag HB, Sweet S, Winchester CC, Dent J. Update on the epidemiyology of gastrooesophageal reflux disease: a systematic review. Gut 2014;63:871-80.

2. DeVault KR, Castell DO; American College of Gastroenterology. Updated guidelines for the diagnosis and treatment of gastroesophageal reflux disease. Am J Gastroenterol 2005;100:190-200.

3. Vakil N, van Zanten SV, Kahrilas P, et al; Global Consensus Group. The Montreal definition and classification of gastroesophageal reflux disease: a global evidence-based consensus. Am J Gastroenterol 2006;101:1900-20.

4. Camilleri M, Dubois D, Coulie B, et al. Prevalence and socioeconomic impact of upper gastrointestinal disorders in the United States: results of the US Upper Gastrointestinal Study. Clin Gastroenterol Hepatol. 2005;3:543-52.

5. Zagari RM, Fuccio L, Wallander MA, et al. Gastrooesophageal reflux symptoms, oesophagitis and Barrett's oesophagus in the general population: the Loiano-Monghidoro study. Gut 2008;57:1354-9.

6. A Gallup Organization National Survey: Heartburn across America. Princeton, NJ, The Gallup Organization, 1988 from uptodate 18.3.

7. Stanghellini $V$. Three-month prevalence rates of gastrointestinal symptoms and the influence of demographic factors: results from the Domestic/International Gastroenterology Surveillance Study (DIGEST). Scand J Gastroenterol Suppl. 1999;231:20-8.

8. Ho KY, Kang JY, Seow A. Prevalence of gastrointestinal symptoms in a multiracial Asian population, with particular reference to refluxtype symptoms. Am J Gastroenterol 1998;93:1816-22.

9. Fujiwara Y, Takahashi S, Arakawa T, et al; IGICS Study Group. A 2008 questionnaire-based survey of gastroesophageal reflux disease and related diseases by physicians in East Asian countries. Digestion 2009;80:119-28.

10. Spechler SJ. Epidemiology and natural history of gastro-oesophageal reflux disease. Digestion 1992;51(Suppl 1):24-9. açık olan bu ilaçların kullanılma yüzdesinin batı toplumlarında daha fazla olması reflü prevalansının da bu toplumlarda daha fazla olmasını da beraberinde getirecektir. Anket çalışmalarının zorluğu daha görüşmenin başında katılımcının ikna olmasının sağlanmasıdır. Sorularının detaylı, anlaşılmaz ve sayısının fazla oluşu görüşmeyi uzatıp verilen yanıtların doğruluğunu azaltırken yarıda bırakıımasına dahi sebep olmaktadır.

Geri dönüş oranı olarak bilinen bu durumun bizim anketimizdeki oranı \%59 idi. Çalışmamız bahsedildiği gibi 2011 yılı Haziran-Ekim ayları arasında yapılmışır. Bu dönem yaşadığımız yerdeki yılın en sıcak zamanlarına rast gelmektedir ve tüm seneyi kapsamamaktadır. Ayrıca verilen tarihler arasına Ramazan Ayı denk gelmektedir. Bu nedenle Konya ili merkez ilçeleri için bulunan GÖRH sıkıı̆ına yaz ayları için prevalans demek daha doğru olacaktır.

Çıkar çakışması: Yazarlar, makalenin yazımı ve basımı açışından çıkar çakışması beyan etmemektedirler.

Finansal destek: Bu çalışma için finansal destek alınmamıştır.

11. Bor S, Mandiacioglu A, Kitapcioglu G, et al. Gastroesophageal reflux disease in a low-income region in Turkey. Am J Gastroenterol 2005;100:759-65.

12. Yonem O, Sivri B, Ozdemir L, et al. Gastroesophageal reflux disease prevalance in the city of Sivas. Turk J Gastroenterol 2013;24:30310.

13. Mungan Z. Prevalance and demographic determinants of gastroesophageal reflux disease (GERD) in the Turkish general population-based cross-sectional study. Turk J Gastroenterol 2012;23:32332.

14. Ergül R, Dağlı Ü, Özmen E, et al. Bolu II Merkezi'nde gastroözofageal reflü hastalığı prevalansı: popülasyona dayalı çalışma. Turk J Gastroenterol 2012;23 (Suppl 1):SS-07.

15. Bor S, Vardar R, Vardar E, et al. Endoscopic findings of gastroesophageal reflux disease in Turkey: Multicenter prospectve study (Gorhen). Gastroenterology 2008;134:4(Suppl 1); A-600.

16. Bor S, Yuksel ES. Gastroözofageal reflü hastalığı prevalansı, insidans ve komplikasyonlarının (striktür/özofajit/Barrett/karsinom) sıklığı dünyanın değişik coğrafi bölgeleriyle karşılaştırıldığında nasıldır? Turk J Gastroenterol 2017;28(Suppl 1):S4-9.

17. Fujiwara $Y$, Higuchi $K$, Watanabe $Y$, et al. Prevalence of gastroesophageal reflux disease and gastroesophageal reflux disease symptoms in Japan. J Gastroenterol Hepatol 2005;20:26-9.

18. Ponce J, Vegazo O, Beltran B, et al; Iberge Study Group. Prevalence of gastrooesophageal reflux disease in Spain and associated factors. Aliment Pharmacol Ther 2006;23:175-84.

19. Nocon M, Keil T, Willich SN. Prevalence and sociodemographics of reflux symptoms in Germany--results from a national survey. Aliment Pharmacol Ther 2006;23:1601-5.

20. Bollschweiler E, Knoppe K, Wolfgarten E, Holscher AH. Prevalence of dysphagia in patients with gastroesophageal reflux in Germany. Dysphagia 2008;23:172-6. 
21. Jung HK, Halder S, McNally M, et al. Overlap of gastro-oesophageal reflux disease and irritable bowel syndrome: prevalence and risk factors in the general population. Aliment Pharmacol Ther 2007;26:453-61.

22. Yuen E, Romney M, Toner RW, et al. Prevalence, knowledge and care patterns for gastro-oesophageal reflux disease in United States minority populations. Aliment Pharmacol Ther 2010;32:645-54.

23. Chiocca JC, Olmos JA, Salis GB, et al; Argentinean Gastro-Oesophageal reflux study group. Prevalence, clinical spectrum and atypical symptoms of gastro-oesophageal reflux in Argentina: a nationwide population-based study. Aliment Pharmacol Ther 2005;22:331-42.

24. Ronkainen J, Aro P, Storskrubb T, et al. Gastrooesophageal reflux symptoms and health-related quality of life in the adult general population-the Kalixanda study. Aliment Pharmacol Ther 2006;23:1725-33.

25. Watson DI, Lally CJ. Prevalence of symptoms and use of medication for gastroesophageal reflux in an Australian community. World $J$ Surg 2009;33:88-94.

26. Mohammed I, Nightingale P, Trudgill NJ. Risk factors for gastro-oesophageal reflux disease symptoms: a community study. Aliment Pharmacol Ther 2005;21:821-7.

27. Mostaghni A, Mehrabani D, Khademolhosseini F, et al. Prevalence and risk factors of gastroesophageal reflux disease in Qashqai migrating nomads, southern Iran. World I Gastroenterol 2009;15:961-5.
28. Türkiye Diyabet, Hipertansiyon, Obezite ve Endokrinolojik Hastalıklar Prevalans Çalışmasi-II (TURDEP-II), http://www.turkendokrin.org/files/file/TURDEP_II_2011.pdf

29. Moshkowitz M, Horowitz N, Halpern Z, Santo E. Gastroesophageal reflux disease symptoms: Prevalence, sociodemographics and treatment patterns in the adult Israeli population. World J Gastroenterol 2011;17:1332-5.

30. Wong BC, Kinoshita Y. Systematic review on epidemiology of gastroesophageal reflux disease in Asia. Clin Gastroenterol Hepatol 2006;4:398-407.

31. Yamagishi $H$, Koike $T$, Ohara $S$, et al. Prevalence of gastroesophageal reflux symptoms in a large unselected general population in Japan. World J Gastroenterol 2008;14:1358-64.

32. Cho YS, Choi MG, Jeong JJ, Chung WC, Lee IS, Kim SW, et al. Prevalence and clinical spectrum of gastroesophageal reflux: a population-based study in Asan-si, Korea. Am J Gastroenterol 2005; 100:747-53.

33. Oğuz D, Köksal AŞ, Özden A. Türkiye' de birinci basamak sağlık kuruluşlarına başvuran hastalarda gastroözofageal reflü hastalığı görülme sıklı̆ı. Akademik Gastroenteroloji Dergisi 2008;7:137-43. 